\title{
SISTEM INFORMASI BINA KELUARGA BALITA (BKB) DESA PULOREJO PURWODADI BERBASIS WEB
}

\author{
Liana Qoni'atul Khoiriyah ${ }^{1}$, Azizah Fatmawati ${ }^{2}$ \\ ${ }^{1}$ Fakultas Komunikasi dan Informatika, Program Studi Informatika, \\ Universitas Muhammadiyah Surakarta \\ email : lianaqoniatul@gmail.com \\ ${ }^{2}$ Universitas Muhammadiyah Surakarta email : \\ af157@ums.ac.id
}

\begin{abstract}
Abstrak
Masalah kesehatan Desa Pulorejo di kelola oleh Gerakan Bina Keluarga Balita (BKB). Selama ini data kesehatan balita Desa Pulorejo di catat secara manual, dimana semua data di tulis dalam sebuah buku sehingga untuk pengelolaannya kurang maksimal. Penelitian ini bertujuan untuk mengembangkan Sistem Informasi Bina Keluarga Balita (BKB) Desa Pulorejo Purwodadi berbasis Web. Pengembangan sistem ini menggunakan metode waterfall yang terstruktur dari analisis kebutuhan, desain sistem, penulisan kode program, pengujian program dan penerapan program. Berdasarkan hasil pengujian black box yang telah dilaksanakan, sistem dapat berjalan sesuai dengan fitur yang telah dirancang sejak awal. Sistem dapat melakukan pencatatan data penimbangan balita tiap bulan. Sedangkan hasil dari pengujian System Usability Scale (SUS) diperoleh nilai rata-rata 77.3 yang menunjukkan bahwa sistem masuk dalam kategori Usable.
\end{abstract}

Kata Kunci : Balita, Desa, Penimbangan, Sistem Informasi.

\section{Pendahuluan}

Kantor desa Pulorejo Purwodadi merupakan salah satu kantor desa yang aktif dalam penyebaran informasi publik, baik mengenai kegiatan desa, kesehatan atau hanya sekedar informasi kepada masyarakat sekitar (Melinda, Borman, \& Susanto, 2017). Salah satu informasi yang menjadi fokus Desa Pulorejo adalah masalah kesehatan. Data kesehatan masyarakat dikelola oleh pemerintah desa untuk mengetahui perkembangan kesehatan masyarakat di desa ini. Hal ini dianggap penting bagi pemerintah desa agar dapat memantau kesehatan masyarakatnya. Gerakan Bina Keluarga Balita (BKB) yang ada di desa Pulorejo Purwodadi merupakan kegiatan yang dikhususkan untuk menangani masalah kesehatan balita desa Pulorejo. Bina Kelurga Balita (BKB) sendiri merupakan kegiatan untuk meningkatkan pemahaman orang tua terhadap perkembangan sang anak. Pengolahan data yang masih dilakukan secara manual memiliki banyak kelemahan, kemungkinan terjadinya kesalahan masih sangat besar sehingga keakuratannya dinilai kurang. Keberadaan teknologi informasi sekarang ini diharapkan mampu mengubah pengolahan data secara manual kedalam bentuk sistem informasi komputer (Andriani, 2009). (Sudarmilah, Supardi, \& Muliawan, 2012) menyatakan bahwa teknologi informasi sudah berkembang dan dirasa cukup maju untuk dimanfaatkan diberbagai bidang. Peran TI dengan sistem informasi yang responsif selalu dianggap sebagai solusi akhir yang bermanfaat yang terintegrasi dengan semua bagian pada sistem (de Vries, 2007). Menyadari akan besarnya manfaat teknologi informasi yang berkembang saat ini, maka diperlukan sebuah sistem baru yang dapat diterapkan di desa Pulorejo sebagai solusi untuk mengatasi hambatan dalam pencatatan data penimbangan balita di desa Pulorejo yang selama ini masih menggunakan sistem manual. Hal ini menjadi salah satu alasan mengapa sistem informasi berbasis online menjadi sarana pengelola data yang mudah, cepat dan biaya yang lebih murah (Nugroho, 2015). Sistem informasi dapat memberikan hasil yang lebih untuk output sebuah sistem, apabila sistem yang ada didalamnya telah berjalan dengan baik (Mulyani \& Purnama, 2015). Selain itu, pemanfaatan kemajuan teknologi yang dapat diakses dimana saja 
memudahkan pemerintah desa dalam melakukan input dan edit data secara langsung sehingga dapat meminimalisir adanya kesalahan dan kehilangan data (Prasetyo, 2017). Diterapkannya sistem Sistem Informasi Bina Keluarga Balita (BKB) berbasis web diharapkan membawa dampak baik daan menguntungkan bagi semua pihak yang berkepentingan. Sistem Informasi berbasis web memberikan kemudahan dalam pencatatan data penimbangan balita pada Bina Keluarga Balita (BKB) desa Pulorejo lebih efektif dengan hasil yang akurat. Dengan adanya sistem yang baru, diharapkan dapat meningkatkan kemajuan dan kualitas sumber daya yang ada di desa Pulorejo dengan dukungan informasi yang lebih mudah dikelola dan diakses. Tentunya Sistem Informasi Bina Keluarga Balita (BKB) berbasis web ini dirancang sesuai dengan kondisi sosial desa Pulorejo yang tujuan akhirnya dapat meningkatkan kualitas desa Pulorejo itu sendiri.

\section{Metode}

Pengembangan sistem ini menggunakan metode waterfall. Metode waterfall merupakan model klasik yang sistematis dan berurutan dalam membangun sebuah software (Pressman, 2014). Metode waterfall mempunyai beberapa tahapan antara lain analisis kebutuhan, perancangan sistem, pembuatan sistem, pengujian sistem, implementasi sistem dan perawatan sistem (Bassil, 2012). Gambar 1 menunjukkan urutan metode waterfall.

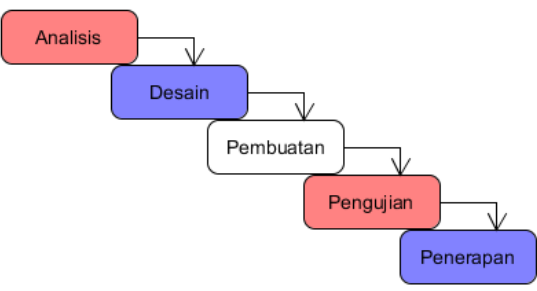

\section{Gambar 1 Tahapan Metode Waterfall}

\subsection{Analisa Kebutuhan}

Pengumpulan data yang dilakukan oleh peneliti menunjukkan bahwa sistem pencatatan data penimbangan balita pada Bina Keluarga Balita (BKB) Desa Pulorejo masih kurang efektif. Maka dari itu diperlukan sistem untuk mengatasi permasalahan tersebut. Yaitu dengan Sistem Informasi Bina Keluarga Balita Desa Pulorejo Purwodadi berbasis web. Kebutuhan fungsional sistem informasi Bina Keluarga Balita (BKB) untuk penimbangan berupa data balita, dan data penimbangan perbulan yang terdiri dari tanggal penimbangan, berat badan balita, dan juga tinggi badan balita. Pengelolaan data dilakukan oleh masing-masing user yang ada di tiap dusun yang di kontrol penuh oleh admin untuk memastikan tidak adanya kesalahan pada input data. Kebutuhan non fungsional pengembangan sistem informasi ini antara lain kebutuhan perangkat keras yaitu laptop untuk masing-masing user. Sedangkan kebutuhan perangkat lunak berupa Operating System menggunakan Windows (XP, 7, 8 10) yang mendukung aplikasi Chrome sebagai Web Browser.

\subsection{Desain Sistem}

Tahapan ini merupakan penerapan ide dan rancang bangun sistem menjadi sebuah program dengan pemodelan use case diagram. Langkah awal pada sistem ini adalah melakukan Login. Admin dan User sebagai aktor dapat melakukan kegiatan yang berhubungan dengan pengelolaan seluruh kegiatan yang terdapat dalam sistem yang berkaitan dengan data penimbangan. Pengelolaan data ini berupa input, edit, delete dan view data (Rahmawati, 2020).

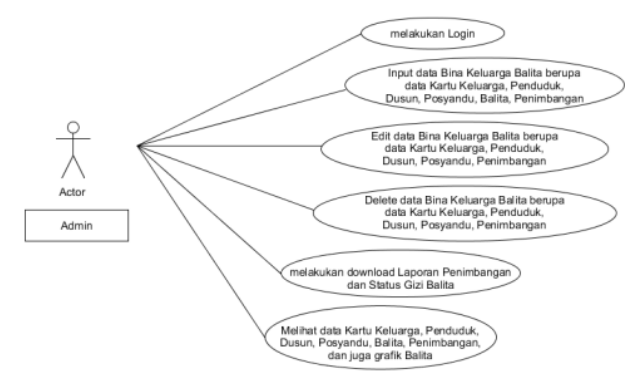

Gambar 2 Use Case Diagram Admin

Dari Gambar 2 dijelaskan bahwa admin memiliki akses lengkap untuk mengelola Sistem Informasi Bina Keluarga Balita (BKB) desa Pulorejo. Admin harus melakukan login untuk mendapatkan akses berupa pengelolaan data, antara lain input, edit, delete, serta download data Penimbangan. 


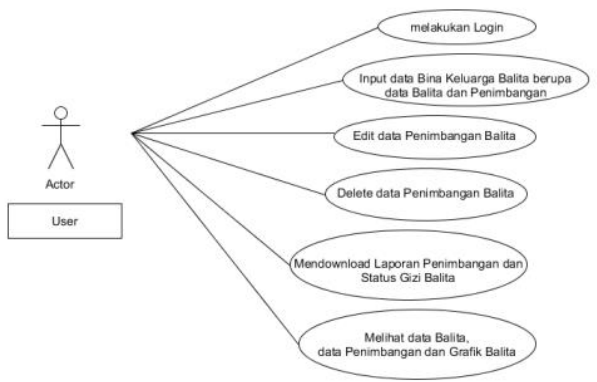

Gambar 3 Use Case Diagram User

Dari Gambar 3 dijelaskan bahwa User memiliki akses untuk mengelola beberapa fungsi yang terdapat pada Sistem Informasi Bina Keluarga Balita (BKB) desa Pulorejo. User harus melakukan login untuk bisa mendapatkan akses melakukan pengelolaan berupa input, edit, delete.

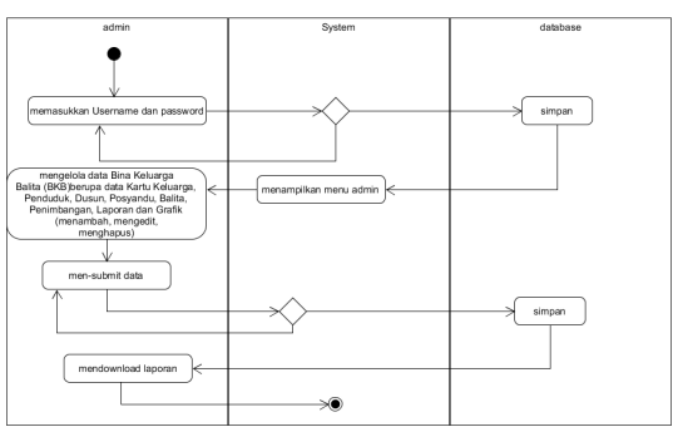

Gambar 4 Activity Diagram Admin

Berdasarkan Gambar 4 dijelaskan bahwa Admin harus melakukan login dengan memasukkan username dan password setelah itu menuju menu utama kemudian melihat detail data kesehatan Bina Keluarga Balita (BKB). Admin Sistem Informasi Bina Keluarga Balita (BKB) dapat melihat data dan mendownload laporan. Admin memiliki tampilan menu yang lengkap karena memiliki akses untuk mengelola sistem informasi. Admin juga dapat mengakses menu laporan yang berisi data lengkap tentang informasi Bina Keluarga Balita (BKB).

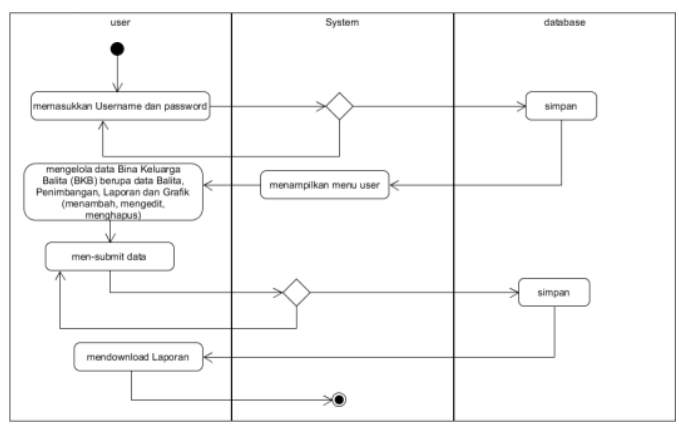

\section{Gambar 5 Activity Diagram User}

Berdasarkan Gambar 5 dijelaskan bahwa User harus melakukan login dengan memasukkan username dan password setelah itu menuju menu utama kemudian melihat detail data kesehatan Bina Keluarga Balita (BKB). User Sistem Informasi Bina Keluarga Balita (BKB) dapat melihat, menambah, menghapus dan mengedit beberapa data yang ada serta dapat mencetak laporan.

\subsection{Penulisan Kode Program}

Berdasarkan desain yang telah dirancang, kemudian ke tahap implementasi yaitu coding untuk memproses menjadi sebuah sistem. Pengkodean pada sistem informasi ini menggunakan bahasa PHP dengan framework PHP yaitu CodeIgniter. Sistem ini juga menggunakan MySQL sebagai database untuk mengembangkan program serta mendukung proses yang dilakukan oleh admin. Sistem dikembangkan dengan acuan kemampuan admin dalam mengaplikasikannya. Langkah ini diambil guna mempermudah admin dalam penggunaan sistem pada saat diterapkan.

\subsection{Pengujian Program}

Tahapan terakhir dalam sebuah pengembangan adalah melakukan pengujian sistem. Pada tahap ini, pengujian melibatkan verifikasi bahwa sistem telah memenuhi spesifikasiya (Bahrani et al., 2019). Pengujian yang digunakan dalam pengebangan sistem ini adalah pengujian dalam bentuk kuisioner dan blacbox yang lebih terfokus pada pengujian fungsionalitas (Kumar, Manish; Singh, 2015). Pengujian kuisioner dilakukan dengan System Usability Scale (SUS). Menurut (Brooke, 2013), System Usability Scale (SUS) merupakan sebuah kuisioner untuk pengukuran usability sistem komputer menurut sudut pandang pengguna. Sedangkan Blackbox testing adalah suatu teknik pengujian perangkat lunak yang berdsarkan pada spesifikasi fungsional dari perangkat lunak dan tanpa menguji kode program (Nidhra, Srinivas; Dondeti, 2012). Hasil dari pengujian nantinya dijadikan acuan untuk memperbaiki sistem dan penyempurnaan sistem sebelum tahap penerapan.

\subsection{Penerapan Program}


Program yang telah melalui proses pengembangan dan pengujian diserahkan kepada user. Penerapan sistem ini diharapkan mampu mengatasi permasalahan pencatatan data Bina Keluarga Balita (BKB). Sistem Informasi ini juga diharapkan mampu menunjang proses pencatatan yang sebelumnya mengalami banyak kendala.

\section{Hasil dan Pembahasan}

Sistem Informasi Bina Keluarga Balita Desa Pulorejo Purwodadi Berbasis Web telah dikembangkan sesuai dengan metode perancangan sistem. Hasil dari penelitian ini berupa sistem informasi berbasis web yang mampu mempermudah kader posyandu dalam pencatatan data balita, penimbangan balita serta laporan kesehatan balita setiap bulannya. Sistem informasi ini memiliki beberapa menu pada halawan awal. Pada header terdapat menu kartu keluarga, penduduk, dusun, posyandu, balita, penimbangan, laporan penimbangan, grafik balita dan logout untuk keluar. Pada setiap halaman, pengelolaan data memiliki fungsi menambah dan menyimpan data kedalam database, mengubah data, mencetak dengan esktensi pdf, serta menghapus data.

\subsection{Halaman Sistem Informasi Bina} Keluarga Balita

Halaman awal Gambar 6 menampilkan dashboard setelah admin melakukan login.

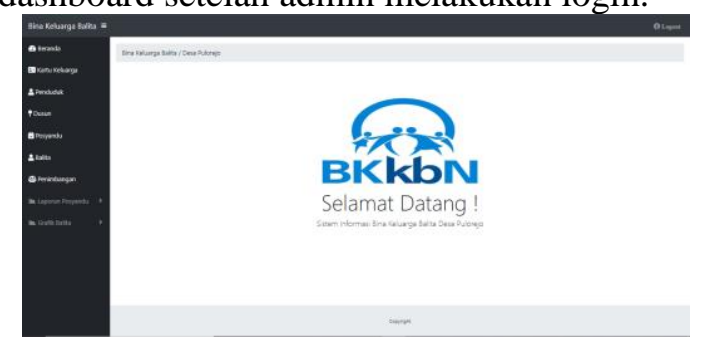

\section{Gambar 6 Halaman Awal Admin}

Halaman awal Gambar 7 menampilkan dashboard setelah user melakukan login.

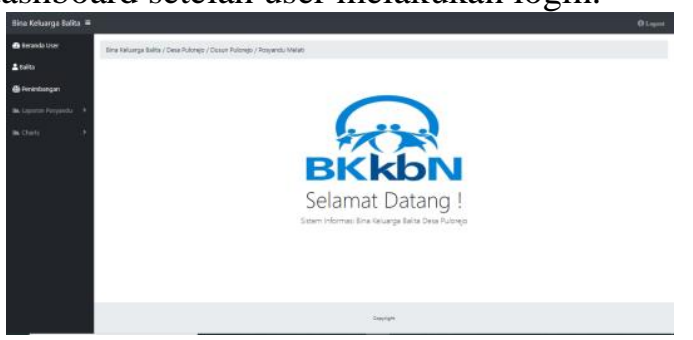

Gambar 7 Halaman Awal User

Halaman kartu keluarga menampilkan data nomor kartu keluarga dan kepala keluarga dengan fungsi menambah, mengubah dan menghapus yang ditunjukkan oleh Gambar 8 .

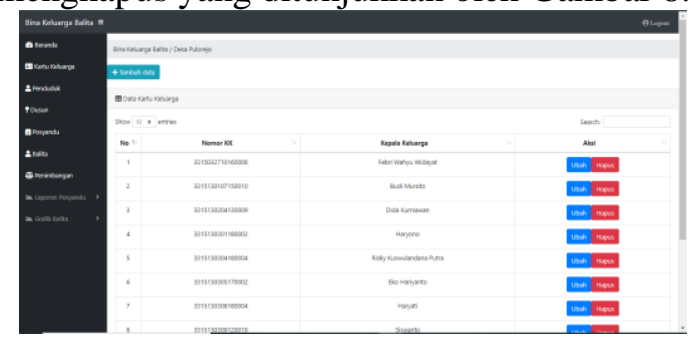

Gambar 8 Halaman Kartu Keluarga

Halaman Penduduk menampilkan data penduduk dengan fungsi menambah, mengubah dan menghapus. Mengubah, apabila terdapat data yang perlu perubahan dan disimpan kembali kedalam database yang ditunjukkan oleh Gambar 9.

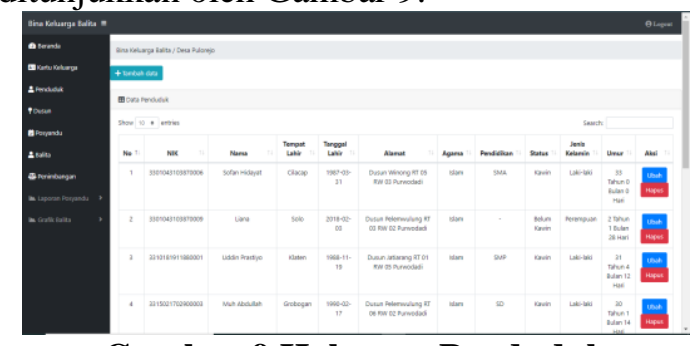

Gambar 9 Halaman Penduduk

Halaman dusun menampilkan data dusun dengan fungsi menambah, mengubah dan menghapus yang ditunjukkan oleh Gambar 10 .

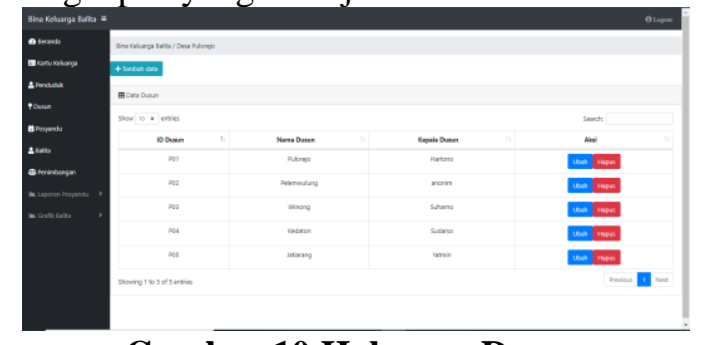

\section{Gambar 10 Halaman Dusun}

Halaman posyandu menampilkan data posyandu dengan fungsi menambah, mengubah dan menghapus yang ditampilkan oleh Gambar 11.

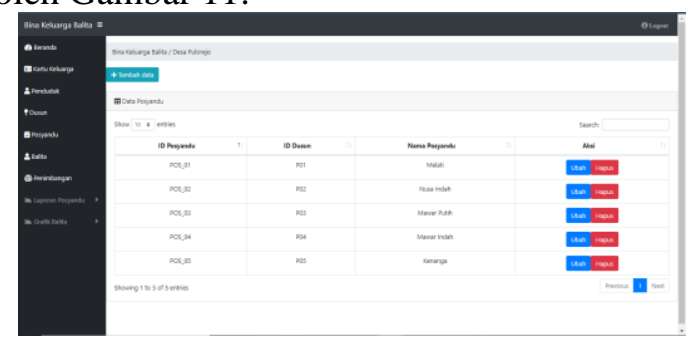

Gambar 11 Halaman Posyandu

Halaman balita menampilkan data balita dengan fungsi detail yang ditunjukkan oleh Gambar 12. 


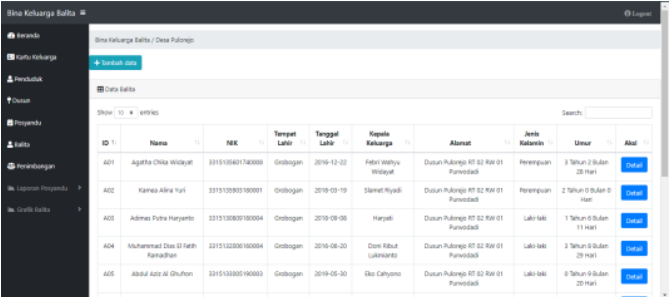

Gambar 12 Halaman Balita

Halaman detail merupakan fungsi pada halaman balita yang menampilkan data balita beserta data penimbangan rutin yang dilaksanakan setiap bulannya ditunjukkan oleh Gambar 13.

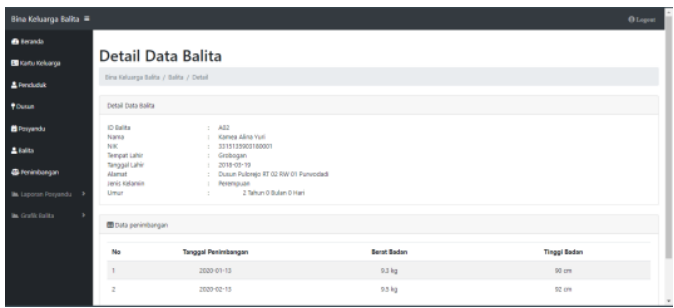

Gambar 13 Halaman Detail

Halaman penimbangan menampilkan data penimbangan keseluruhan balita yang dilakukan setiap bulannya dengan fungsi menambah, megubah dan menghapus yang ditunjukkan oleh Gambar 14.

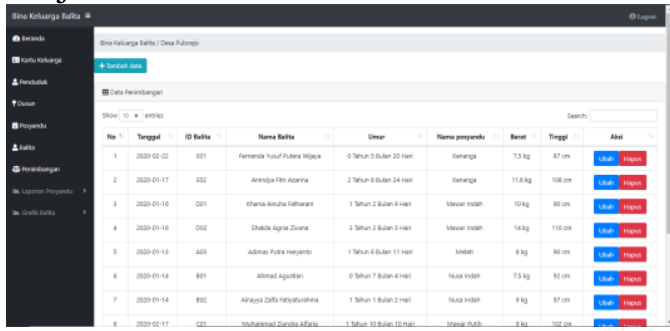

Gambar 14 Halaman Penimbangan

Gambar 15 menampilkan halaman laporan penimbangan yang dapat dilihat per bulannya. Laporan dapat dicetak dalam bentuk pdf yang berisi tanggal, data balita serta data timbangan sesuai bulan yang telah dipilih.

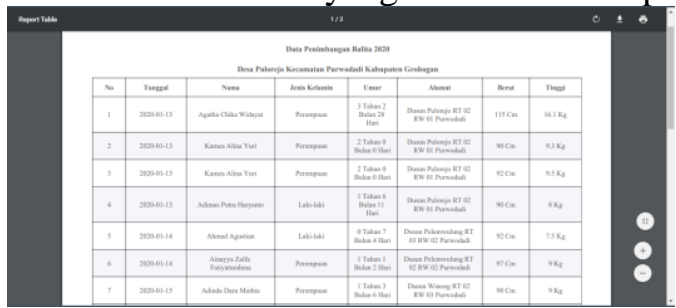

Gambar 15 Halaman Laporan Timbangan

Seperti halnya laporan penimbangan, Gambar 16 menunjukkan hasil laporan status gizi balita yang dapat dilihat per bulannya. Laporan status gizi ini dapat dicetak dalam bemtuk pdf yang berisi tanggal, data balita, data timbangan, serta status gizi balita sesuai

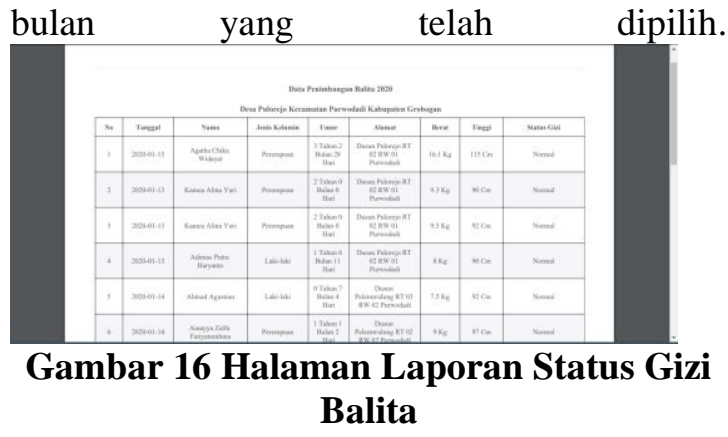

Dapat dilihat pada Gambar 17 yang menampilkan grafik perbandingan jumlah persebaran balita yang terdapat pada lima dusun di Desa Pulorejo. Hal ini dapat menunjukkan adanya pertumbuhan penduduk pada Desa Pulorejo terutama di masingmasing dusun.

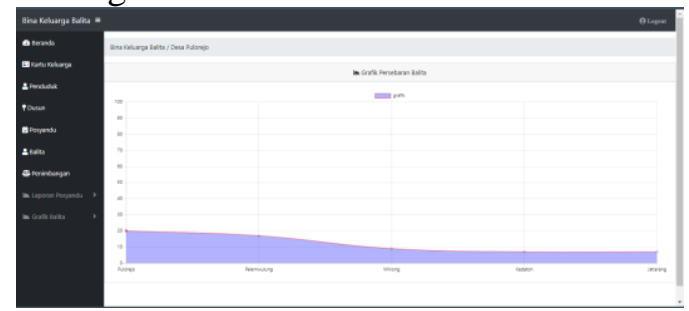

Gambar 17 Grafik Persebaran Balita

Gambar 18 menampilkan grafik perbandingan jumlah jenis kelamin balita keseluruhan yang ada di Desa Pulorejo. Dari grafik tersebut dapat memudahkan petugas dalam melihat kondisi perbandingan jenis kelamin laki-laki dan perempuan pada tiap dusunnya.

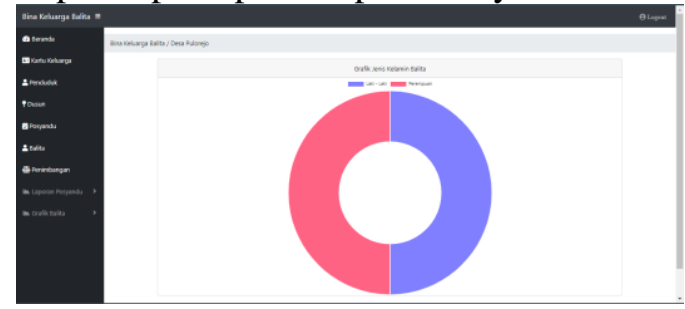

\section{Gambar 18 Grafik Jenis Kelamin Balita}

\subsection{Pengujian Black Box}

Untuk memastikan sistem yang dikembangkan telah berjalan dengan baik atau tidak dilakukan pengujian black-box. Hasil dari pengujian black box menyatakan bahwa sistem telah berjalan sesuai dengan fitur dan fungsinya sesuai rancangan di awal.

\subsection{Pengujian System Usability Scale}

Menurut (Brooke, 2013), System Usability Scale (SUS) merupakan sebuah kuisioner untuk pengukuran usability sistem komputer menurut sudut pandang pengguna. Terdiri dari sepuluh pertanyaan sederhana 
dengan lima poin skala Likert yaitu poin 1 berarti Sangat Tidak Setuju (STS) hingga poin 5 berarti Sangat Setuju (SS). Perhitungan hasil SUS sebagai berikut :

1. Perhitungan nilai skor memperhatikan angka ganjil atau genap dari setiap pernyataan. 2. Pernyataan nomor ganjil dihitung dari nilai jawaban dikurangi 1 , pernyataan nomor genap adalah 5 dikurangi dengan pernyataan yang dipilih.

3. Nilai diperoleh dikalikan 2.5 setiap skor lalu totalnya dijumlahkan.

4. Klasifikasi rata-rata skor :

a. Usable, nilai diatas 75

b. Marginal, rata-rata nilai SUS antara 50-75 memiliki arti diperlukan peningkatan system yang telah dikembangkan.

c. Unacceptable, jika rata-rata nilai SUS dibawah 50 yang berarti system yang dikembangkan tidak dapat diterima.

Berdasarkan hasil pengujian SUS yang disebar kepada 33 responden nilai rata-rata yang diperoleh 77.3 yang berarti sistem termasuk dalam kategori Usable.

\section{Kesimpulan dan Saran}

\section{Kesimpulan}

Berdasarkan pengujian black box yang telah dilakukan, sistem berjalan sesuai dengan fitur serta fungsi yang dirancang dari tahap awal. Pengujian mendapatkan hasil yang baik, dimana tidak terdapat error pada saat input data kartu keluarga, penduduk, dusun, posyandu, balita, penimbangan serta cetak laporan dan grafik. Pengujian kedua yang dilakukan dengan kuisioner SUS mendapatkan nilai rata-rata 77.3 yang termasuk dalam kategori Usable.

\section{Saran}

Sistem Informasi Bina Keluarga Balita masih belum sempurna sehingga dapat dikembangkan lagi menjadi lebih baik. Perbaikan pada tampilan web dan juga penambahan grafik status gizi balita untuk mempermudah pendataan balita kurang sehat yang ada di Desa Pulorejo.

\section{Daftar Pustaka}

Andriani, L. (2009). Sistem Informasi Pendaftaran Pasien Rawat Jalan Di
Rumah Sakit Dengan Menggunakan Program Komputer.

Bahrani, Hidayati, N., Listyorini, T., Listiawan, T., Kartini, Y. E., Chusna, N. L., ... Sallu, S. (2019). A Design of Innovation in Educational Technology to Improve the Quality of Website Learning in Industrial Revolution Era 4.0 Using Waterfall Method. Journal of Physics: Conference Series, 1364(1), 0-5.

Bassil, Y. (2012). Sistem Informasi Pelayanan Administrasi

Kependudukan Dan Catatan Sipil Kelurahan Di Kecamatan Marangkayu Kutai Kartanegara. Jurnal Rekayasa Teknologi Informasi, 2(1), 47-54.

Brooke, J. (2013). A retrospective. Usability Evaluation in Industry, 189(194), 4-7.

de Vries, J. (2007). Diagnosing inventory management systems: An empirical evaluation of a conceptual approach. International Journal of Production Economics, 108(1-2), 63-73.

Kumar, Manish; Singh, S. K. ;Dr. R. K. D. (2015). A Comparative Study of Black Box Testing and White Box Testing. International Journal of Computer Sciences and Engineering, 5(12), 301-304.

Melinda, M., Borman, R. I., \& Susanto, E. R. (2017). Rancang Bangun Sistem Informasi Publik Berbasis Web ( Studi Kasus : Desa Durian Keamatan Padang Cermin Kabupaten Pesawaran ). 11(1), 1-4.

Nidhra, Srinivas; Dondeti, J. (2012). Black Box and White Box Testing Techniques - A Literature Review. International Journal of Embedded Systems and Applications, 2(2), 2950 .

Nugroho, Y. S. (2015). Pengembangan Manajemen Data Elektronik Paud Di 
Pac Aisyiyah Kecamatan Tingkir, Salatiga. Warta, 18, 110-117.

Petersen, K. (2009). The Waterfall Model in Large-Scale Development. 2015 IEEE Canada International Humanitarian Technology Conference, IHTC 2015, 386-400.

Prasetyo, W. D. (2017). Sistem informasi inventaris desa berbasis web.

Pressman, R. S. (2014). Software Quality Engineering: A Practitioner's Approach. In Software Quality Engineering: A Practitioner's Approach (Vol. 9781118592).

Rahmawati, A. D. (2020). Sistem administrasi desa mendiro kecamatan ngrambe kabupaten ngawi berbasis web. SISTEM ADMINISTRASI DESA MENDIRO KECAMATAN NGRAMBE KABUPATEN NGAWI BERBASIS WEB.

Sudarmilah, E., Supardi, A., \& Muliawan, E. A. (2012). Aplikasi Administrasi Laboratorium Pada Rumah Sakit PKU Muhammadiyah Delanggu. Jurnal Emitor, 12(01), 8-15. 